УдК 792.83:793.31(477.87)

DOI: 10.31866/2616-7646.4.2.2021.249288

\title{
ОСОБЛИВОСТІ ПРОСТОРОВОЇ КОМПОЗИЦІЇ НАРОДНО-СЦЕНІЧНИХ ТАНЦІВ УКРАЇНЦІВ ЗАКАРПАТТЯ
}

\author{
Тимчула Андрій Васильович, \\ кандидат мистецтвознавства, \\ старший викладач, \\ Київський національний університет культури і мистецтв, \\ Київ, Україна, \\ https://orcid.org/0000-0002-8287-6852 \\ tymchula_adukr.net \\ Яценко Ольга Леонідівна, \\ заслужена артистка України, \\ доцент кафедри, \\ Київський національний університет культури і мистецтв, \\ Київ, Україна, \\ https://orcid.org/0000-0001-9809-4284, \\ zhemchuzhnaQukr.net
}

Мета статті - виявити специфіку сценічних інтерпретацій фольклорних танців українців Закарпаття на основі аналізу просторової композиції народно-сценічних танців другої половини XX - початку XXI ст. Методологія. Застосовано методи структурного та формального аналізу просторової композиції хореографії народно-сценічних танців; типологічний метод спрямований на виявлення локальних особливостей традиційної танцювальної культури українців Закарпаття; порівняльний метод застосовано для зіставлення народних та народно-сценічних танців крізь призму поняття «формація» (за А. Джурческу). Наукова новизна. Проаналізовано специфіку сценічної інтерпретації традиційних танців українців Закарпаття крізь призму концепції «формацій» А. Джурческу. Висновки. Структурно-просторова композиція народно-сценічних танців українців Закарпаття побудована на специфічних мізансценах та «формаціях». Мізансцени в проаналізованих хореографічних композиціях («Дробойка», «Увиванець», «Дібровчанка», «Чинадійка», «Дубкани-скакани», «Березнянка», «Дуботанець», «Лісоруби», «Коломийка», «Водичанський скаканий», «Карпатське чудо-озеро», «Мараморощина квітуча») - це завершені сцени 3 гармонічною 3 художньо-естетичного погляду наявністю формацій в кожному танці. Характерними є регулярні зміни статичних та динамічних фігур. Зміни в мізансценах переважно відповідають музичному супроводу. В межах мізансцени наявні різноманітні складники формації - групування (від соло до численних групи - 16 та більше танцюристів); кількість (залежить від кількості танцюристів в ансамблі); гендерний склад учасників; геометрична конфігурація (малюнок) - переважають напівколо та замкнене коло, лінії; взаємоорієнтування танцюристів; спосіб зв’язку між танцюристами - руки схрещені попереду, за поясом та ін. Відмінності між проаналізованими хореографічними композиціями народних та народно-сценічних танців є наслідком індивідуального творчого бачення хореографа-постановника. Це помітно на рівні групування та кількості танцюристів, їхніх зв’язків, порядку використання обраних геометричних конфігурацій.

Ключові слова: фольклорний танець; народно-сценічний танець; просторова композиція танцю; українці Закарпаття. 


\section{ОСОБЕННОСТИ ПРОСТРАНСТВЕННОЙ КОМПОЗИЦИИ НАРОДНО- СЦЕНИЧЕСКИХ ТАНЦЕВ УКРАИНЦЕВ ЗАКАРПАТЬЯ}

Тымчула Андрей Васильевич,

кандидат искусствоведения, старший преподаватель,

Киевский национальный университет

культуры и искусств,

Киев, Украина,

https://orcid.org/0000-0002-8287-6852, tymchula_adukr.net

Яценко Ольга Леонидовна, заслуженная артистка Украины, доцент,

Киевский национальный университет культуры и искусств, Киев, Украина,

https://orcid.org/0000-0001-9809-4284, zhemchuzhnaQuukr.net

Цель статьи - выявить специфику сценических интерпретаций фольклорных танцев украинцев Закарпатья на основе анализа пространственной композиции народно-сценических танцев второй половины XX - начала XXI ст. Методология. Использованы методы структурного и формального анализа пространственной композиции хореографии народно-сценических танцев; типологический метод направлен на выявление локальных особенностей традиционной танцевальной культуры украинцев Закарпатья; сравнительный метод применен для сопоставления народных и народно-сценических танцев через призму понятия «формация» (по А. Джурческу). Научная новизна. Проанализирована специфика сценической интерпретации традиционных танцев украинцев Закарпатья сквозь призму концепции «формаций» А. Джурческу. Выводы. Структурно-пространственная композиция народно-сценических танцев украинцев Закарпатья построена на специфических мизансценах и формациях. Мизансцены в проанализированных хореографических композициях («Дробойка», «Увиванец», «Ди-

\section{PECULIARITIES OF SPATIAL COMPOSITION OF FOLK AND STAGE DANCES OF UKRAINIANS IN ZAKARPATTIA}

\author{
Tymchula Andrii \\ PhD in Art Studies, \\ Senior Lecturer, \\ Kyiv National University \\ of Culture and Arts, \\ Kyiv, Ukraine, \\ https://orcid.org/0000-0002-8287-6852, \\ tymchula_adukr.net \\ Olha Yatsenko, \\ Honored Artist of Ukraine, \\ Associate Professor, \\ Kyiv National University \\ of Culture and Arts, \\ Kyiv, Ukraine, \\ https://orcid.org/0000-0001-9809-4284, \\ zhemchuzhnadukr.net
}

The purpose of the article is to reveal the stage interpretations' specifics of folklore dances of Ukrainians in Zakarpattia based on the analysis of the spatial composition of folk stage dances in the second half of the 20th early 21 st century. Research methodology. The methods of structural and formal analysis of the spatial composition of the folk stage dances' choreography were used; the typological method is aimed at identifying the local features of the traditional dance culture of Ukrainians in Zakarpattia; the comparative method is used to compare folk and folk stage dances through the prism of the concept of 'formation' (according to A. Giurchescu). Scientific novelty. The stage interpretation specificity of traditional dances of Ukrainians in Zakarpattia through the prism of the concept of 'formations' by A. Giurchescu is analyzed. Conclusions. The structural-spatial composition of folk-stage dances of the Ukrainians in Zakarpattia is built on specific mise-en-scenes and formations. Mise-en-scenes in the analyzed choreographic compositions ('Droboika', 'Uvyvanets', 'Dibrovchanka', 'Chynadiika', 'Dubkany-skakany', 'Bereznianka', 'Dubota- 
бровчанка», «Чинадийка», «Дубканы-скаканы», «Березнянка», «Дуботанец», «Лесорубы», «Коломыйка», «Водычанский скаканый» «Карпатское чудо-озеро», «Мараморощина квитуча») - это завершенные сцены с гармоничным с художественно-эстетической точки зрения наличием формаций в каждом танце. Характерны регулярные изменения статических и динамических фигур. Изменения в мизансценах в основном соответствуют музыкальному сопровождению. В рамках мизансцены имеются различные составляющие формации - группировка (от соло до многочисленных групп - 16 и более танцоров), количество (зависит от количества танцоров в ансамбле), гендерный состав участников; геометрическая конфигурация (рисунок) - преобладают полукруг и замкнутый круг, линии; взаимоориентация танцоров, способ связи между танцорами - руки скрещены впереди, за поясом и др. Различия между проанализированными хореографическими композициями народных и народно-сценических танцев являются следствием индивидуального творческого видения хореографа-постановщика. Это заметно на уровне группирования и количества танцоров, их связей, порядка использования выбранных геометрических конфигураций.

Ключевые слова: фольклорный танец; народно-сценический танец; пространственная композиция танц̧а; украинцы Закарпатья.

Актуальність теми дослідження. 3 позиції сучасної хорелогії хореографія розглядається як мистецтво ство- nets', 'Lisoruby', 'Kolomyika', 'Vodychanskyi skakanyi', 'Karpatske chudo-ozero', 'Maramoroshchyna kvitucha') are completed scenes with harmonious formations in each dance from an artistic and aesthetic point of view. Regular changes of static and dynamic figures are characteristic. The changes in the mise-enscène mostly correspond to the musical accompaniment. Within the framework of the miseen-scene, there are various components of the formation - a grouping (from solo to numerous groups (16 or more dancers), the number (depending on the number of dancers in the ensemble), the gender composition of the participants; geometric configuration (drawing) a semicircle and a vicious circle, lines predominate; mutual orientation of dancers, the way of communication between dancers - arms crossed in front, behind the belt, etc. The differences between the analyzed choreographic compositions of folk and folk-stage dances are a consequence of the individual creative vision of the choreographer-director. This is noticeable at the level of grouping and the number of dancers, their connections, order using the selected geometric configurations.

Keywords: folk dance; folk stage dance; spatial composition of the dance; Ukrainians of Zakarpattia.

рення танцю, його об’єднання з музичним супроводом у гармонійне художнє ціле. Набутки світової практики хореографічного мистецтва в умовах міжкультурної взаємодії другої половини XX - початку XXI ст. посприяли поширенню багатьох танцювальних тенденцій, новаторських елементів сценічного руху, нестандартних засобів вираження та ін. Розвиваючись серед різноманіття хореографічних стилів, у специфічних історико-культурних умовах, народні танці українців Закарпаття завдяки творчості аматорських та професійних колективів, а головне унікальному авторському баченню балетмейстерів-постановників, набули нової сценічної хореографічної форми. 
Актуальність дослідження зумовлена необхідністю осмислення специфіки сценічної інтерпретації народного танцю бойків, лемків, долинян та гуцулів у контексті розвитку хореографічного мистецтва другої половини XX - початку XXI ст.

Аналіз останніх досліджень та публікацій засвідчив відсутність у доробку науковців мистецтвознавчих досліджень, присвячених виявленню особливостей народно-сценічних танців українців Закарпаття. Натомість більш грунтовно проаналізовано фольклорні танці лемків, бойків і гуцулів Прикарпаття та поставлені на їх основі сценічні хореографічні композиції. Окремі аспекти проблематики сценічного втілення народного танцю західного регіону України висвітлено у наукових працях О. Бігус (2016), О. Квецко (2015), Б. Стасько (2004), О. Фабрики-Процької (2019) та ін.

Мета статті - виявити специфіку сценічних інтерпретацій фольклорних танців українців Закарпаття на основі аналізу просторової композиції народно-сценічних танців другої половини XX - початку XXI ст.

Виклад основного матеріалу. Сценічний простір у хореографічному мистецтві зазвичай визначається як певне місце (в приміщенні або простонеба), в умовах якого група танцюристів виконує танці, а глядач відділений від виконавців. Відповідно хореографія народно-сценічного танцю належить до категорії презентаційного танцю, на відміну від танцю партисипативного, специфіка якого полягає у відсутності реальної відмінності між танцюристом і глядачем.

У праці Д. Уільямса «Антропологія та танець» наведено відмінності між структурованим семантичним простором, в якому відбуваються події, - внутрішнім простором - та використанням простору, що є внутрішнім стосовно системи знаку дії - він $є$ внутрішньою формою. Дослідник наголошує, що «... простір виконання, в якому перебувають глядачі, танцюристи й театр, відділений від простору внутрішнього» (Williams, 2004, p. 226). Тобто, простір, в якому відбувається хореографічна постановка, відділений від шаблонів просторових шляхів та рухів танцюристів - безпосередньо від самого танцю. Таким чином, внутрішній простір форми конкретного танцю може бути відтворений в різних просторових театральних просторах.

За А. Іберсфельд, сценічний простір - це місце «конкретного театру», що розуміється як діяльність, що відбувається в космосі. Натомість сценічне місце - це обмежена та ізольована частина простору, місце, де відбувається дія. Це конкретний простір, в якому «... існують відносини між тілами танцюристів і в якому також можна знайти розвиток фізичної активності, танців, спокушання та боротьби» (Ibersfeld, 1982, p. 119). Дослідниця наголошує, що місце сцени попередньо кодується залежно від сценічних звичок певного періоду.

Сцена, як специфічний майданчик мистецтва або конкретне місце, має визначену структуру, що формує спосіб презентації танцю, відповідно позиціонується деякими дослідниками як своєрідна «модель події» (як театр, стадіон та церква) або рамка живописного твору, що тісно пов'язана зі змістом та $є$ частиною композиції (Arnheim, 1988, p. 244). Так, на думку Р. Арнхейма, сцена (рамка) - це основа, на якій будується композиція, саме вона визначає зміст та межі роботи та є необхідною частиною композицій, що визначає центр рівноваги й просторове положення всіх елементів хореографічної картини (Arnheim, 1988, p. 87). 
Зазвичай хореографи народно-сценічного танцю використовують принцип відкритої прямокутної сцени, тоді як створення нових творів послідовниками Р. Лабана передбачає складання різних сценічних планів (Laban, 2011). Відомий словацький хореограф Ш. Носаль, описуючи різноманітні типи сцени, акцентує увагу на тому, що передусім сценічний простір асоціюється зі звичайною сценою, обмеженою з трьох боків та відкритою з одного боку для глядача, так званим театром просценіуму (Nosal, 1984, p. 50). У праці «Хореографія народного танцюв він наголошує, що вся сценічна зона з точки зору аудиторії може бути поділена на активні або менш активні точки, лінії та поверхні (Nosal, 1984, pp. 50-52).

Враховуючи геометричні та динамічні властивості простору, Р. Арнхейм підкреслює важливість центральної точки, яку він описує як «фокус енергії, що спрямовує вектори» на навколишнє середовище і $є$ місцем, в якому вектори здаються концентричними (Arnheim, 1988, p. 28). У. Клайн наголошує на динамічних процесах (крещендо та демінуендо), що в хореографічних термінах пов’язані з просторовою композицією і належать до динаміки змін малюнківції, що призводять до зміни центру рівноваги (цей принцип, з огляду на кількість учасників на сцені, відстань між ними та інші аспекти, є надзвичайно важливим) (Klajn, 1995, p. 147).

Сценічний простір як зовнішній простір із власними межами, активними точками та векторами, що спрямовані в центральну точку, впливає на внутрішню структуру хореографії народно-сценічного танцю, що складається з візуальних елементів.

Внутрішній простір - це просторова галузь конкретної хореографії, поняття, що безпосередньо пов’язане з концепцією просторової композиції. Поняття «формування» та «положення в просторі» позиціонуються теоретиками та практиками народно-сценічного танцю як складники морфології танцю. Наприклад, А. Джурческу визначає положення у просторі як систему з чотирма складниками - групуванням, кількістю, формою та взаємним орієнтуванням тіл, що розглядаються під загальним терміном «формація» (Giurchescu \& Bloland, 1995, p. 83).

Також «формацію танцю» можна розглядати як систему, що включає шість параметрів:

- кількість танцюристів;

- групування танцюристів;

- гендерна приналежність виконавців (чоловічий, жіночий, змішаний склад в хореографічній композиціі);

- форма або геометрична конфігурація формації (малюнок): коло, півколо, лінія та ін.;

- взаємоорієнтування танцюристів - обличчям один до одного, спиною один до одного, боком один до одного та ін.;

- зв’язок між танцюристами: виконавці тримаються за руки, схрестивши їх попереду, за спиною та ін.

На основі аналізу найвідоміших фольклорних танців бойків («Феся», «Кочан»,«Вививанець», «Вівчарські коломийки», «Волосянські співані», «Обертаний»), лемків («Ровна», «Коломийка», «Обертак», «Лемківський танець», «Карічка» «Дупак», «Обертак», «Потряска», «Круглий», «Гусій танець», «Крижованец», «Мотаний танець або танець без конца», «Качки», «Мости» «На собітку»), гуцулів («Рівна», «Висока», «Трясунка», «Голуб», «Півторак», «Чабан», «Гребінець», «Зірниця», «Цебра», «Гуцулка», «Аркан»), та долинян («Увиванець», «Людська сколомийка», 
«Меньосоньтанц») виявлено, що традиційні танці українців Закарпаття виконуються в формації, що переважно лишається незмінною протягом усього танцю.

Натомість мистецтвознавчий аналіз хореографічних композицій народно-сценічних танців українців Закарпаття, а саме: «Увиванець» та «Дубкани-скакани» (балетмейстер В. Ангаров, 1946 р.); «Березнянка» (балетмейстер П. Вірський та К. Балог, 1964 р.); «Дуботанець» (балетмейстер І. Попович), «Лісоруби» (балетмейстер Й. Волощук, обробка І. Поповича), «Коломийка» (балетмейстер М. Ромадов, 1968-1969 рр.), «Карпатське чудо-озеро» (постановка І. Пастеляка, І. Шевцової, М. Шютіва, Є. Бабяк, О. Хижун, 2016 р.), «Дробойка», «Дібровчанка» (авторська хореографія К. Балог, постановка І. Пастеляка), «Чинадійка» (авторська хореографія К. Балог, постановка Ж. Короловича), «Мараморощина квітуча» та «Водичанський скаканий» (авторська хореографія Й. Волощука, постановка М. Герман) дає підстави стверджувати, що в хореографії народно-сценічних танців відбуваються постійні зміни різних складників формації, оскільки ці твори поставлені балетмейстерами, в них багато змінних параметрів.

Характерними для танцювальної культури українців Закарпаття є: закрита кругова фігура (танцюристи кладуть руки на плечі один одному або схрещують їх за спиною); фігури, що побудовані з кількох кіл концентрично (у центрі кола - соліст або пара); композиційні особливості лемківського народного танцю характеризуються різноманіттям складання фігур та використанням повторень, а також поперечними лініями малюнка танців. Серед найбільш поширених у народній хореографічній культурі гуцулів фігур - «коло», «ряд», «зірниця», «хрещик», «букет», «корито».

Загальною рисою танців гуцулів, бойків та лемків є рух колом та за похідними від кола побудовами; численні притупи; рухи направлені не лише вперед, а в сторони та до центра кола. Крім вступу до танцю («розводити танець»), де танцюристи-чоловіки виконують здебільшого притупи та кругові рухи, у гуцулів виконуються колективно стрибки за командою керівника, а в бойків та лемків - стрибки окремих танцюристів. У двофігурних структурах танців основною вважається друга фігура, а в трифігурних - центральна. У деяких танцях танцюрист чи пара танцюристів після соло у центрі кола сходять з майданчика.

У хореографії зміни малюнків, угруповань (фігур) $є$ найбільш очевидними, оскільки відбуваються у певний час, з певною динамікою. Кожна фігура має власну тривалість та власні, так звані, перехідні моменти, що починають та завершують її. Це створює певний ритм із чергуванням статичних та динамічних сегментів. Статичні сегменти прагнуть фіксованих утворень, а динамічні - генерують перехідні моменти, в яких траєкторії відіграють вирішальну роль. Малюнок, траєкторія у танцях - синонім лінії в образотворчому мистецтві (крапка, що рухається у просторі та може варіюватися за шириною, довжиною, спрямуванням), простежується на макро- та мікрорівнях: переміщення на макрорівнях поєднують дві сцени або мізансцени, а переміщення на мікрорівнях відбуваються на рівні однієї фігури.

Звертаючись до терміна «мізансцена» в контексті народно-сценічного танцю, наголосимо, що він нерідко використовується в різноманітних наукових працях, предметом дослідження яких є хореографія сучасного або класичного танцю. Враховуючи специфіку використання поняття мізансцена в театральному та кіномистецтві, воно $є$ надзвичайно доречним у контексті аналізу просторового 
виміру хореографії народно-сценічного танцю. У цьому разі можемо визначити його як гармонічне з художньо-естетичної точки зору розміщення окремих закінчених сцен, що відбуваються у певний момент на сцені разом із розміщенням інших візуальних елементів, як-от костюми, освітлення, реквізит та інші елементи сценографії.

Відповідно зміни мізансцени створюють порядок у часі, що $є$ не просто суб’єктивним та довільним (Arnheim, 1988, p. 242). Зміни мізансцени змінюють центр рівноваги, а перехід між двома різними центрами, на думку Р. Арнхейма, якщо він поєднаний з попередньою та/або наступною структурою, має сенсове навантаження (Arnheim, 1988, p. 243).

Аналізуючи народні танці українців Закарпаття, можемо зазначити, що вони були функціонально визначені ритуальним контекстом та його значенням. Саме у танцювальній культурі бойків, лемків, долинян та гуцулів найбільше збереглися дохристиянські елементи - у хореографічній лексиці наявні яскраві язичницькі ритуали, зокрема, хореографічна будова - фігура «коло», яку передусім робили для посилення виголошених у текстах танечних пісень побажань ритуалом магічного танцювального руху колом, у напрямку за сонцем. На думку багатьох дослідників, танцювання колом в календарній обрядовості українців Закарпаття є символом циклічності моделі часу - нескінченного руху сонця небосхилом, колообігу природи, а традиційне використання його у родинній (весільній) обрядовості пов'язують із віруванням у магічні сили давнього оберега - кола, а триразове виконання, тобто рух колом тричі (функційно-семантичний троїстий зв'язок) походить від дохристиянських ритуалів та культів - троїсте Боже начало спостерігається ще в язичницьких віруваннях давніх слов'ян (наприклад, Триглав як божественний принцип триєдності світу; троїстість богів Перуна, Сварога та Світовида; символізм трьох сфер буття).

Свята календарного циклу, а відтак і притаманні кожному святу особливі ритуали, прикмети та обряди (відповідно до смислового навантаження), а також релігійні обряди, танці, пісні та заклинання, які іх супроводжували, залежали насамперед від особливостей моральної, духовної та традиційної господарської культури кожної етнографічної групи.

У народно-сценічному танці структура танцю має соціальну конотацію. Отже, інтерпретація фольклорного танцю - це не лише зовнішні зміни, а й трансформація його функцій. На відміну від функціонального взаємозв’язку елементів у традиційному танці, формації та мізансцени в хореографії народно-сценічного танцю виконують передусім естетичну функцію.

Сучасні балетмейстери шляхом поєднання кількох елементів різних рухів відповідно до жанрових або стильових особливостей, образно-тематичного розвитку танцю та локальних особливостей хореографічної лексики українців Закарпаття в залежності від районування урізноманітнюють та увиразнюють, такі рухи і кроки, як вихиляси, тропітка, крутитися, оборотів крок, гайдук, дрібушечки, підківки, потряска, рівна або низька погорянка, приставний крок вперед та назад, плетена доріжка з перекиданням ніг, припадання з підскоком і викиданням поперемінно ніг, синкоповані комбіновані ходи на каблук та ін. (Василенко, 1997, с. 173), що дає можливість створювати складні характери та образи для відтворення. Різнома- 
ніття формацій народних танцях українців Закарпаття надає великі можливості для інтерпретування їхньої хореографії, зокрема, у її просторовому вимірі.

Наукова новизна. Проаналізовано специфіку сценічної інтерпретації традиційних танців українців Закарпаття крізь призму концепції «формацій» А. Джурческу.

Висновки. Структурно-просторова композиція народно-сценічних танців українців Закарпаття побудована на специфічних мізансценах та «формаціяХ». Мізансцени в проаналізованих хореографічних композиціях («Дробойка», «Увиванець», «Дібровчанка», «Чинадійка», «Дубкани-скакани», «Березнянка», «Дуботанець», «Лісоруби», «Коломийка», «Водичанський скаканий», «Карпатське чудо-озеро», «Мараморощина квітуча») - це завершені сцени з гармонічною 3 художньо-естетичного погляду наявністю формацій у кожному танці. Характерними є регулярні зміни статичних та динамічних фігур. Зміни в мізансценах переважно відповідають музичному супроводу. В межах мізансцени наявні різноманітні складники формації - групування (від соло до численних групи - 16 та більше танцюристів); кількість (залежить від кількості танцюристів в ансамблі); гендерний склад учасників; геометрична конфігурація (малюнок) - переважають напівколо та замкнене коло, лінії; взаємоорієнтування танцюристів; спосіб зв’язку між танцюристами - руки схрещені попереду, за поясом та ін. Відмінності між проаналізованими хореографічними композиціями народних та народно-сценічних танців $є$ наслідком індивідуального творчого бачення хореографа-постановника. Це помітно на рівні групування та кількості танцюристів, їхніх зв’язків, порядку використання обраних геометричних конфігурацій.

\section{СПИСОК ПОСИЛАНЬ}

Бігус, О. О. (2016). Народно-сценічна хореографія Прикарпатського регіону. Видавництво Ліpa-K.

Василенко, К. Ю. (1997). Український танець. ІПК ПК.

Квецко, О. Я. (2015). Бойківський танець в контексті розвитку українського народно-сценічного танцю. Молодий вчений, 12(27, ч. 4), 54-57.

Стасько, Б. (2004). Хореографічне мистецтво Івано-Франківщини. Лілея-НВ.

Фабрика-Процька, О. Р. (2019). Виконавська діяльність народного ансамблю пісні і танцю «Лемковина» у контексті розвитку українського народнопісенного мистецтва (до 50-річного ювілею). В Л. І. Горіна (Ред.), Актуальні проблеми народно-інструментального виконавства в Україні: історія і сучасність (с. 114-122). Волинські обереги.

Arnheim, R. (1988). The Power of the Center: A Study of Composition in the Visual Arts. University of California Press.

Giurchescu, A., \& Bloland, S. (1995). Romanian traditional dance: A contextual and structural approach. Wild Flower Press.

Ibersfeld, A. (1982). Čitanje pozorišta (Zodijak br. 55). Vuk Karadžić.

Klajn, H. (1995). Osnovni Problemi Režije (3-e izd.). Univerzitet umetnosti u Beogradu.

Laban, R. (2011). The mastery of movement (L. Ullmann, Ed.; $4^{\text {th }}$ ed.). Dance Books.

Nosál, Š. (1984). Choreografia L'udového Tanca. Slovenské Pedagogické Nakladatel'stvo.

Williams, D. (2004). Antropology and the Dance: Ten lectures (2nd ed). University of Illinois Press. 


\section{REFERENCES}

Arnheim, R. (1988). The Power of the Center: A Study of Composition in the Visual Arts. University of California Press.

Bihus, O. (2016). Narodno-Stsenichna Khoreohrafiia Prykarpatskoho Rehionu [Folk-Stage Choreography of the Prykarpattia Region]. Lira-K [in Ukrainian].

Fabryka-Protska, O. (2019). Vykonavska Diialnist Narodnoho Ansambliu Pisni i Tantsiu "Lemkovyna" u Konteksti Rozvytku Ukrainskoho Narodnopisennoho Mystetstva (do 50-richnoho Yuvileiu) [Performing Activity of the Folk Song and Dance Ensemble "Lemkovyna" in the Context of the Development of Ukrainian Folk Song Art (to the 50th Anniversary)]. In L. Horina (Ed.), Aktualni Problemy Narodno-Instrumentalnoho Vykonavstva v Ukraini: Istoriia i Suchasnist [Actual Problems of Folk Instrumental Performance in Ukraine: History and Modernity] (pp. 114-122). Volyncki oberehy [in Ukrainian].

Giurchescu, A., \& Bloland, S. (1995). Romanian Traditional Dance: A Contextual and Structural Approach. Wild Flover Press.

Ibersfeld, A. (1982). Čitanje Pozorišta (Zodijak br. 55) [Reading Theater (Zodiac no. 55)]. Vuk Karadžić [in Serbian].

Klajn, H. (1995). Osnovni Problemi Režije [Basic Problems of Directing] (3rd ed.). University of Arts in Belgrade [in Serbian].

Kvetsko, O. Ya. (2015). Boikivskyi Tanets v Konteksti Rozvytku Ukrainskoho NarodnoStsenichnoho Tantsiu [Boyko's Dance in the Context of Ukrainian Folk Stage Dance]. Molodyi Vchenyi [Young Scientist], 12(27, 4), 54-57 [in Ukrainian].

Laban, R. (2011). The Mastery of Movement (L. Ullmann, Ed.; $4^{\text {th }}$ ed.). Dance Books.

Nosál, Š.(1984). Choreografia L'udového Tanca [Folk Dance Choreography]. Slovenské pedagogické nakladatel'stvo [in Slovak].

Stasko, B. (2004). Khoreohrafichne Mystetstvo Ivano-Frankivshchyny [Choreographic Art of IvanoFrankivsk Region]. Lileia-NV [in Ukrainian].

Vasylenko, K. (1997). Ukrainskyi Tanets [Ukrainian Dance]. IPK PK [in Ukrainian].

Williams, D. (2004). Antropology and the Dance: Ten Lectures (2nd ed). University of Illinois Press. 